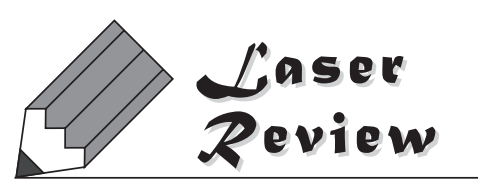

\title{
シリコンフォトニクスによる光デバイスの小型化と集積化
}

\author{
中村滋 \\ NEC グリーンイノベーション研究所（テ305-8501 茨城県つくば市御幸ヶ丘34）
}

\section{Ultra-Small Optical Devices and Their Integration with Silicon Photonics Technology}

\author{
Shigeru NAKAMURA \\ Green Innovation Res. Labs., NEC Corporation, 34 Miyukigaoka, Tsukuba, Ibaraki 305-8501
}

(Received March 23, 2012)

\begin{abstract}
Developing ultra-small optical devices and integrating them are quite useful for realizing energy efficient optical devices and also constructing ICT systems with newly introducing such optical devices. For this purpose, silicon photonics is quite promising. In this report, we briefly review recent silicon photonics technology trends and then focus on optical switching devices based on silicon photonics. A silicon thermo-optical switch element is driven with low heating power. To integrate many elements and construct functional devices with energy efficiency, we need to establish several points, such as high uniformity, polarization independence, and ambient temperature independence. We demonstrate high extinction ratio switching of the $1 \times 8$ optical switch with meeting above-mentioned points for energy efficiency. Such optical switches can be applied to R-OADMs in photonic networks, which provide flexible optical path setup and thus contribute to energy efficient systems.
\end{abstract}

Key Words: Silicon photonics, Optical switch, Thermo-optical effect, Photonic integration, Photonic network

1. はじめに

情報処理・伝送技術 $(\mathrm{ICT})$ の役割は, 今や, その利活 用により持続可能社会を構築するという現代社会の根本 的な課題解決のためのインフラとして重要になってきて いる. 役割の拡大に伴い取り扱う情報量の拡大が今後も 予想されているが, これに対応していくために, ICTの 基盤としての光伝送技術にも，システムを構成する様々 なレイヤでの省エネルギー化の実現が求められている.

光伝送技術の分野では, 光デバイスの小型化・集積化 を進めることで, 光デバイスそのものを省エネルギー化 すると共に, 光デバイス・光伝送が導入可能な領域を拡 大してICT機器・システムを省エネルギー化する取り組 みが進められてきた。この光デバイス小型化・集積化の 今後を担う技術として, 近年, シリコンフォトニクスへ の注目が高まっている，本誌では，2007年に「シリコン フォトニクスの最前線」が特集されており各種の微小光 デバイスに関する優れた解説がある1)。その後, 様々な 応用領域への導入を念頭に集積化技術が急速に進んでき た。本稿では, シリコンフォトニクスによる集積化の現 状を概観すると共に, 我々が取り組みを進めている広域 光ネットワーク向け光スイッチ技術に関して, 省エネル ギー化への貢献ポイントを中心に紹介する.
2. シリコンフォトニクス

Fig. 1に示すように，シリコンフォトニクスという技 術領域は

1) シリコンをコアとし石英をクラッドとする高屈折率差 の光導波路をベースとする各種の微小光デバイス

2)微小光デバイスを要素とする光回路集積化および光回 路・電子回路融合集積化

3）LSI産業で発展してきたCMOSプロセスの活用による 経済的にリーズナブルな高精度加工

で特徴づけられ，各々の技術は，近年，急速な広がりを 見せている。 その応用領域も, 光伝送にとどまらない可

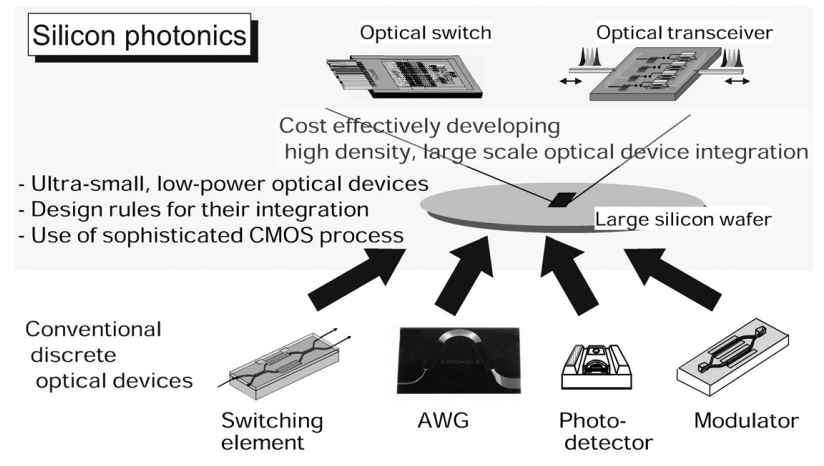

Fig. 1 Concept of silicon photonics. 
能性も持っているが, 光伝送における応用領域として は,

a)装置間, 装置内ボード間, ボード内チップ間, チップ 内の光インターコネクト

b) 広域光ネットワーク向けの光トランシーバ

c) 広域光ネットワーク向けの光スイッチ等の光パス制御 が考えられ，各々，実用化に向けた動きが活発になって いる.

光インターコネクトの領域では, Luxtera社が装置間 接続用にいち早く実用化を進め, $10 \mathrm{Gbps} \times 4 \mathrm{ch}$ の光変 調器・受光器・それらに接続するドライバやアンプ等の 電子回路をシリコンのワンチップにモノリシック集積し Active Optical Cable (AOC) 規格のパッケージで製品化し た2)、ただ，その後のLuxtera社の動向を見ると，光回路 と電子回路は個別に作成した後にハイブリッドに集積す るという方向に向かっているようであり，また， VCSEL等の競合技術でも実現できるAOCではなくシリ コンフォトニクスの小型・集積化メリットをより打ち出 せるボード間接続あるいはチップ間接続に向かっている ように思われる ${ }^{3)}$. ボード間接続あるいはチップ間接続 では, 将来的に1〜10 Tbps級の容量が必要となることが 想定されており，これに向けて光変調器および受光器の 高密度集積化, これらの光回路や電子回路とのハイブ リッド集積化の実証が進み始めている ${ }^{4-6)}$. チップ内接 続に向けては光回路と電子回路のモノリシック集積化の 展望が開けるかどうかがポイントとなるが，当面は八イ ブリッド集積化への取り組みが中心になると思われる。

広域光ネットワーク向けには市場規模からみてシリコ ンフォトニクスのメリットを生かせるのかどうかという 議論もあるが, 活用を想定するCMOSプロセスの世代を 広く捉えればメリットを生かせる可能性は高いと考え る. 光トランシーバの領域では, デジタルコヒーレント 光信号の送受信部の光回路 ${ }^{7)}$, あるいは, マルチコア
ファイバあるいはマルチモードファイバによる空間多重 光信号の分離器8)，等の報告があり，今後ますます複雑 化が予想される光信号の変調方式や多重方式に向けて必 要となる集積光回路の実現が期待される. また, 光ス イッチ等の光パス制御の領域は, 熱光スイッチ素子 ${ }^{9)}$ 多数集積化した各種の光回路の報告があり ${ }^{10-16)}$ ，光ネッ トワークにおける光パス設定自由度を向上させる手段と して期待される。この光スイッチ用途については後述す る.

シリコンフォトニクスにおいて重要なポイントは，標 準的なCMOSプロセスの活用である。LSIの分野では Mooreの法則に沿う形で微細加工技術が進展してきてお り，最近の約10年で線幅(ハーフピッチ)は130 nm $\rightarrow$ $90 \mathrm{~nm} \rightarrow 65 \mathrm{~nm} \rightarrow 45 \mathrm{~nm} \rightarrow 32 \mathrm{~nm}$ と進んできた。最近は微 細化された分だけLSIの動作電圧, 動作電力を低減する ことは困難になっているが, 微細化自体の進展は著しい ものがある. しかし, 最先端の微細加工技術はまだマス クもプロセスも高価であり，大量の汎用LSIの生産に用 いることで初めて経済的に成り立つものであるから，光 デバイスに対しては想定する市場規模に合わせて何世代 か前の加工技術の活用することが前提となる，見方を変 えれば，後々の市場規模の拡大に伴い高精度の加工技術 を適用しようとしたときに，そのためのプロセス基盤が 用意されていると考えることもできる．微細化の世代毎 に規定される加工精度に対して光導波路断面を始めとす る光デバイスの設計を合わせていく必要があるが，例え ば，シリコン光導波路の断面積は, Fig. 2 に示すように, リブ型から細線型まで調整することが可能である。研究 開発段階で利用可能なファウンドリーサービスが，欧州 のimec, LETI, シンガポールのIME等の研究機関から提 供されており, LSI 同様のモデルでの研究開発の加速 が期待される。

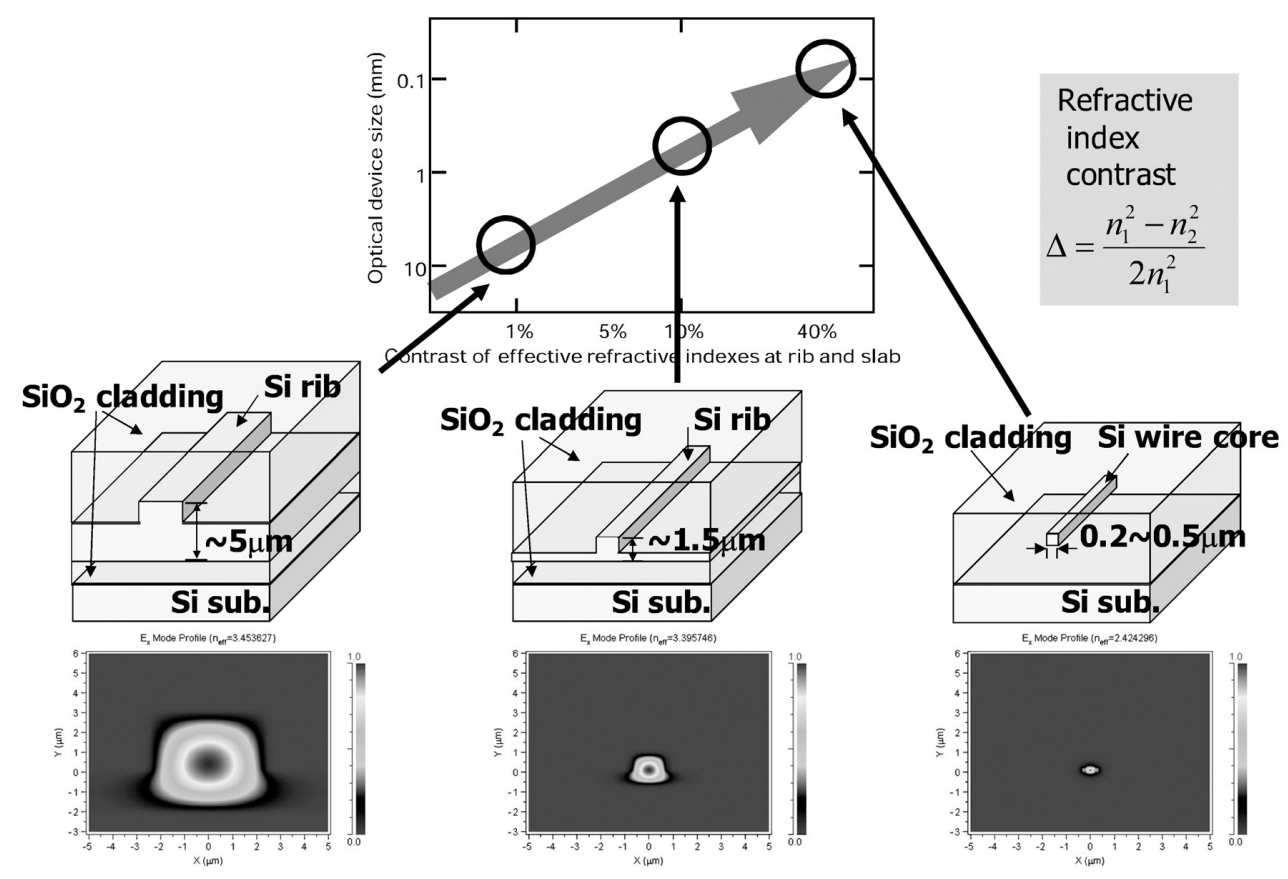

Fig. 2 Option in silicon optical waveguide cross section. 


\section{3. シリコン熱光学スイッチ素子と これを集積化した光回路}

シリコン光導波路を用いた小型・低電力の光スイッチ 素子を多数集積化することにより，多様な光パス制御機 能を提供する光スイッチの実現が可能になる. 光スイッ チは, 波長選択スイッチと呼ばれるものも含めると, 空 間光学系あるいは石英光導波路に基づく方式が, 広域光 ネットワーク向けの装置に向けて導入されてきている。 しかし，今後予想される規模拡大一の対応，あるいは， 広域光ネットワークにとどまらずデータセンター等の多 様な適用領域へ光パス制御の導入を進め上うとすると, 光スイッチにはサイズ・電力・機能集積化の観点で一層 の技術革新が求められる。従来にない小型・低電力・機 能集積の光スイッチの実現可能性を有するシリコンフォ トニクスへの期待は大きい

シリコン光導波路を用いた光スイッチ素子としては, これまでに様々な方式が提案されているが, 大別すれ ば, 駆動方式として熱光学効果またはキャリアプラズマ 効果, 形態としてリング共振器またはマッハ・ツェンダ (Mach-Zehnder, MZ)干渉計となろう ${ }^{9-19)}$ 。これらの素子 を多数集積化して構成される光パス制御用の光スイッチ としては, 小型, 低電力という特徵に加え, 基本的な特 性としては, 低損失, 高消光比, 偏光無依存が求めら れ, さらに, 多くの場合, 環境温度無依存, 高均一な波 長特性等が望まれる。まず，集積の対象となる素子自体 が小型, 低電力, 低損失である必要がある。キャリアプ ラズマ効果を用いる場合，高速動作が可能であるが，熱 光学効果を用いる場合に比べて, 単位長さあたりの位相 シフト量を得にくく光損失も大きくなる。 リング共振器 を用いる場合，著しく小型化できる可能性はあるが，均 一な波長特性が求められる場合には使いにくいし, 環境

(a)

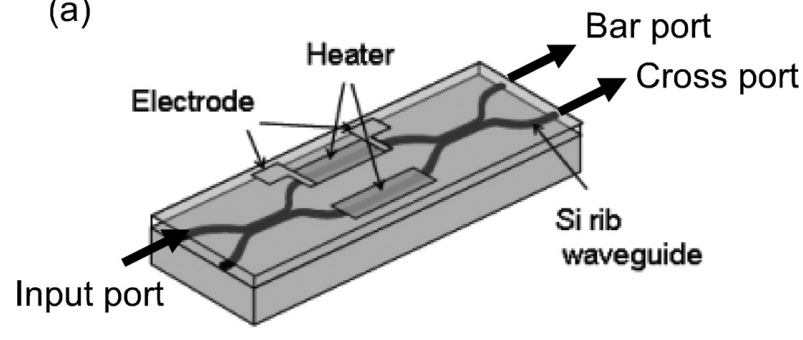

(b)

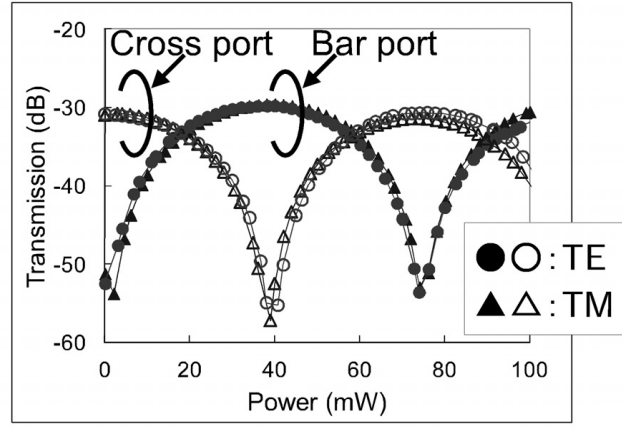

Fig. 3 Silicon thermo-optical Mach-Zehnder switch element. (a) Structure. (b) Typical switching characteristics. TE: Transverse-electric mode. TM: Transverse-magnetic mode.
温度に著しく依存する。これらの観点から，我々として は, 光スイッチ素子を多数集積し, 特に, 多段接続して 集積光回路を構成する場合には，熱光学効果を用いる MZ型素子による構成が有望と考えている ${ }^{10-16)}$. 以下, 我々の光スイッチに関する取り組みを，特に省エネル ギーで駆動可能にするという観点を中心に述べる。

Fig. 3は, 集積光回路の基本要素となるMZ型熱光久 イッチ素子の構造と特性例である. Si層厚 $1.5 \mu \mathrm{m}$ の Silicon-on-Insulator (SOI) 基板上に形成したリブ型光導波 路を用いており，8インチウェハに対する $248 \mathrm{nmUV}$ 露光 を用いた標準的なCMOSプロセスを用いて作成してい る. $2 \times 20 \mathrm{MZ}$ 型において, 熱印加なしでBarポート出 カオフ $\cdot$ Crossポート出力オン (Cross状態), 片アームの ヒータに $35 \sim 40 \mathrm{~mW}$ 程度の電力を与え加熱した状態で Crossポート出力オフ・Barポート出力オン (Bar状態) と なり,そのオンオフ消光比 $25 \mathrm{~dB}$ とる特性がTE (Transverse-electric) モードに対してもTM(Transversemagnetic) モードに対しても得られており, 偏光無依存 動作が得られている. MZ型素子自体の光損失は, 分岐 合流部 2 个所での過剩損失 $0.2 \mathrm{~dB}$ 程度 ${ }^{20)}$ とすることが可 能であり，熱印加に伴う光損失の増加はほぼゼロであ る。また，Fig. 3のように，熱印加なしでCross状態また はBar状態を確実に得ることは，多数素子集積を考える 場合，重要なポイントであり，もし，Cross状態もBar状 態も素子個別に熱印加量の調整を行う必要があると光ス イッチを構成する全ての素子に熱印加を行う必要が生 じ，集積光回路全体での消費電力が大きくなってしま う。また，偏光無依存が得られない場合には，偏光ダイ バシティの手法で光回路を構成する必要があるが, 基本 的には光回路規模が 2 倍になり, 集積光回路全体での消 費電力が大きくなってしまう，すなわち，多数集積化へ の展望を得るためには，MZ型熱光スイッチ素子として Fig. 3の特性を歩留まり良く得ることが重要と考えられ る.

集積光回路を，非温調で使用することができれば，温 調電力が不要になる。リング共振器, 非対称 $\mathrm{MZ}, \mathrm{AWG}$ (Arrayed Waveguide Grating) 等の波長特性を有する光デ バイスをシリコン光導波路で形成した場合には，波長特 性はシリコンの屈折率温度係数に基づく温度依存性を持 つ. スロット構造化して有機材料等のシリコンと逆の屈 折率温度依存性を有する材料で埋め込むことでシリコン 光導波路の実効屈折率の温度無依存化を図り, 波長特性 を有する光デバイスの温度無依存化を目指す取り組み211 もあるが，広い温度範囲への適用にはまだ困難があり， 当面は温調付きで使用することを考えることにならう。 他方, Fig. 3に示した対称なMZ型熱光スイッチ素子は, 基本的に波長特性を持たないので，熱印加なしの状態で あれば温度依存性を示さない。しかし，片アームを加熱 した状態では温度特性を有することに注意する必要があ る。ヒータ加熱により生じる屈折率変化 $(\Delta n)$ は,

$$
\Delta n=\frac{d n}{d T} \Delta T=\frac{d n}{d T} \cdot \rho \cdot P=\frac{d n}{d T} \cdot \rho \cdot \frac{V^{2}}{R}=\frac{d n}{d T} \cdot \rho \cdot I^{2} R
$$



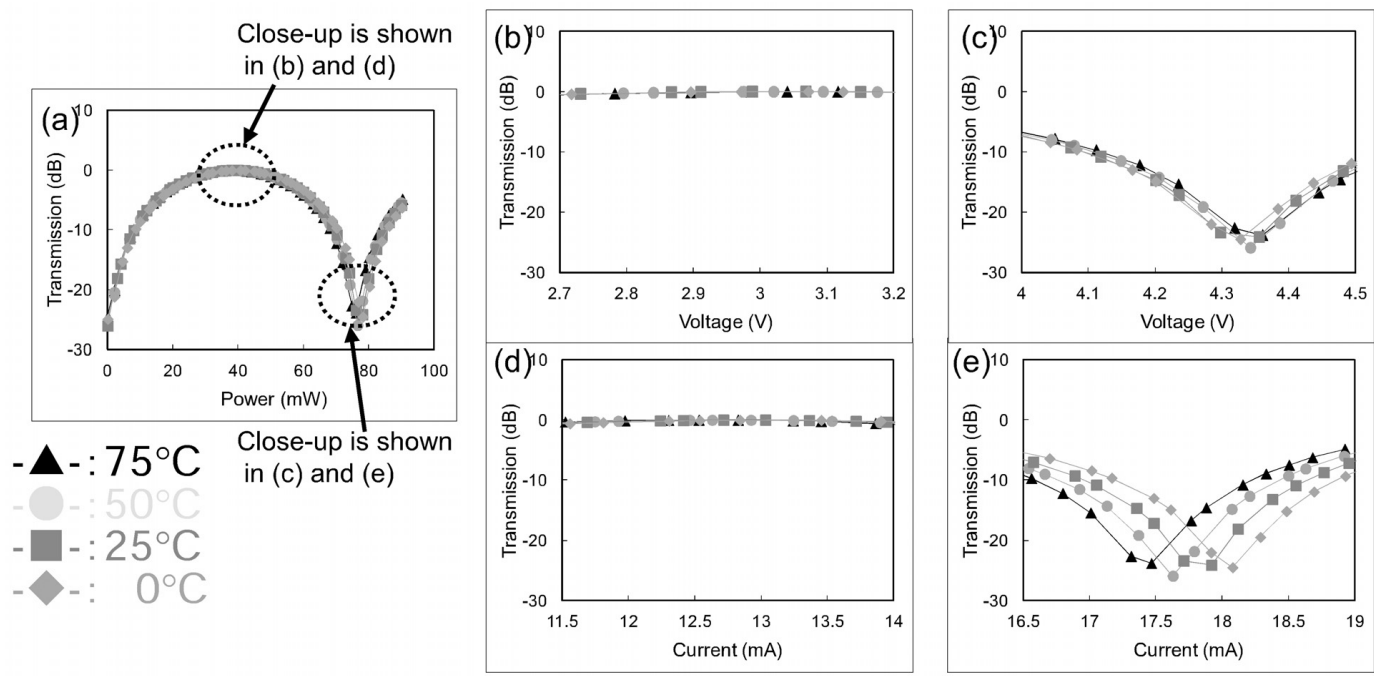

Fig. 4 Temperature dependence of switching characteristics. (a) Horizontal axis: power. (b)-(c) Horizontal axis: voltage. (d)-(e) Horizontal axis: current.

ここで, $d n / d T$ は屈折率温度係数, $\Delta T$ はヒー夕加熱によ る温度変化量, さらに, この $\Delta T$ はヒータへの印加電力 $P$ に比例する(比例係数： $\rho$ ) とし, ヒータにおける抵抗 $R$,

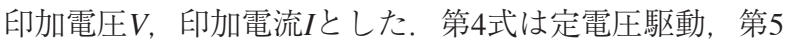
式は定電流駆動，に対応する。 $d n / d T$ は温度上昇に伴い 増加し ${ }^{22}$ ，また， $R$ も一般に金属ヒー夕を用いる場合は 温度上昇に伴い増加する。第4式からわかるように定電 圧駆動の場合にはdn/dTの温度依存性とRの温度依存性は 相殺される可能性がある。また，第5式から，定電流駆 動の場合には $\Delta n$ は温度依存性を示すことになる。電流 ドライバは通常は定電流駆動であるため, 環境温度無依 存化のためにはこの熱光学効果の温度依存性に注意する 必要がある. Fig. 4は実際にMZ型熱光スイッチ素子の温 度特性を評価した結果である。温度 $0{ }^{\circ} \mathrm{C} \sim 75^{\circ} \mathrm{C}$ 範囲 で測定を行った。Fig. 4 (a) はヒータ印加電力に対する Barポートからの光出力をプロットしたものであり, Fig. 4 (b), Fig. 4 (c) は横軸をヒー夕印加電圧にとり直 して光出力極大值付近 (Bar状態), 光出力極小值付近 (Cross状態)を示したもの, Fig. 4 (d), Fig. 4 (e)は横軸 をヒータ印加電流にとり直してBar状態, Cross状態での 光出力を示したものである. Fig. 4 (b), Fig. 4 (d) から わかるように光出力極大值では環境温度の影響は小さ い. Fig. 4 (c) は, 定電圧駆動であれば光出力極小值付 近でも環境温度の影響を低減することが可能であること を示している. Fig. 4 (e) は, 定電流駆動の場合には光
出力極小值付近で環境温度の影響は大きく現れる。すな わち, 環境温度が上昇すると, 出力極小值を与える電流 值は減少することを示している。 なお，Fig.4 (c)，Fig.4 (e) いずれの場合も, 電圧あるいは電流のゆらぎによる光出 力の変動が大きいと予想されることがわかる.

通常の定電流駆動のドライバを用いる場合でも，環境 温度に依存せずに高消光比を得るためには光回路の構成 上の工夫が必要になる。Fig. 5は, $1 \times 8$ 光スイッチを ゲートの役割をする素子とセレクタの役割をする素子で 構成した場合を示す。ゲート部には12個の熱光スイッチ 素子を用いているが，各々の素子が小さいので，ゲート 部全体でも $1 \mathrm{~mm} \times 3 \mathrm{~mm}$ 領域におさまっている.

Fig. 6は, この $1 \times 8$ 光スイッチにおいて各々の光経路の オンオフ特性を測定した結果である。Fig. 5からわかる ように各々の光経路がオフになる場合には，2個のヒー 夕加熱されていない素子で光信号が遮断されており，こ れにより環境温度に依存せずに高消光比が得られること が期待される. Fig. 6 (a)からわかるように，波長50 nm の範囲で均一, 偏光無依存, 消光比 $40 \mathrm{~dB}$ 以上の特性が 確認された。 また, Fig.6（b)からわかるように，温度 $0{ }^{\circ} \mathrm{C} \sim 75^{\circ} \mathrm{C}$ 範囲でオンオフ特性には違いは見られな いことが確認された。

以上, 熱光スイッチ素子そのものは, 高い屈折率温度 係数のおかげで, 低電力駆動が可能であり省エネルギー と言えるものの，これを集積した光回路を省エネルギー (a)

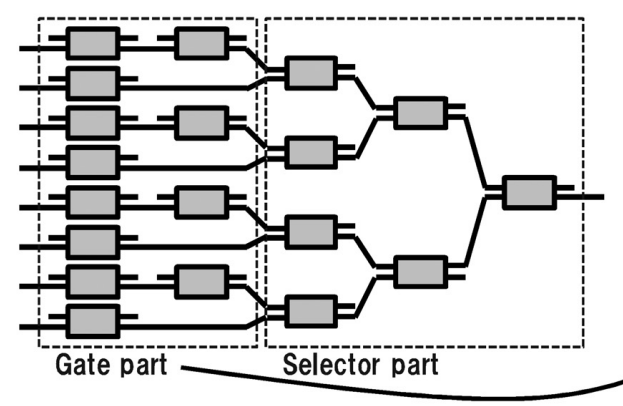

(b)

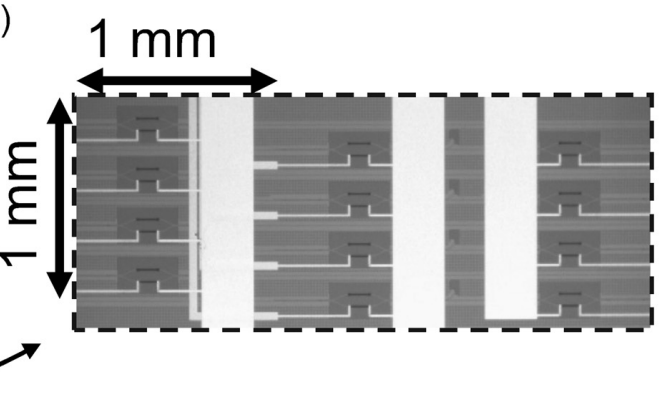

Fig. 5 (a) Configuration of $1 \times 8$ selector switch. (b) Photograph at gate part. 

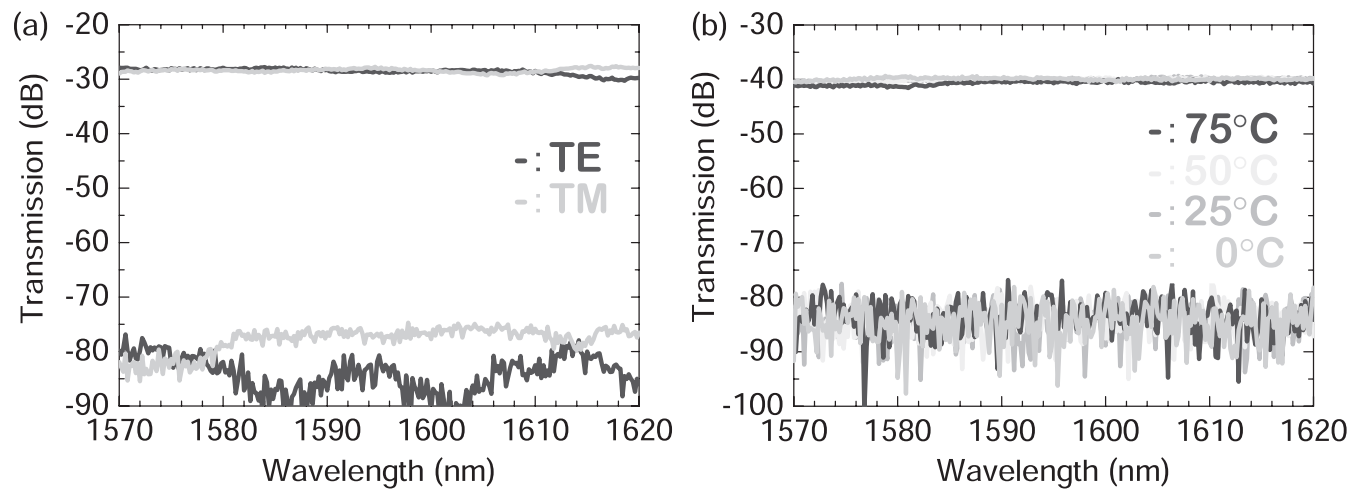

Fig. 6 Transmission spectra showing on and off states of $1 \times 8$ selector switch (a) Polarization dependence (b) Temperature dependence.

で動作させるには，いくつかポイントがあることを示し た。すなわち，素子を個別に調整することを不要にする 均一性, 偏光ダイバシティを不要にする偏光無依存化, 温調を不要にする環境温度無依存化が必要になる。熱光 スイッチ素子を集積した光回路で構成する $1 \times 8$ 光ス イッチにおいてこれらの特性を実証した．熱光スイッチ 素子自体の光損失は低いが, これを集積化した光回路を 活用していく上で, 光ファイバとの結合における光損失 を十分に抑える必要がある. 光回路チップ端面で光ファ イバのモード径に整合させるようシリコン光導波路の モード径を拡大させる構造が提案されている ${ }^{23-25)}$.
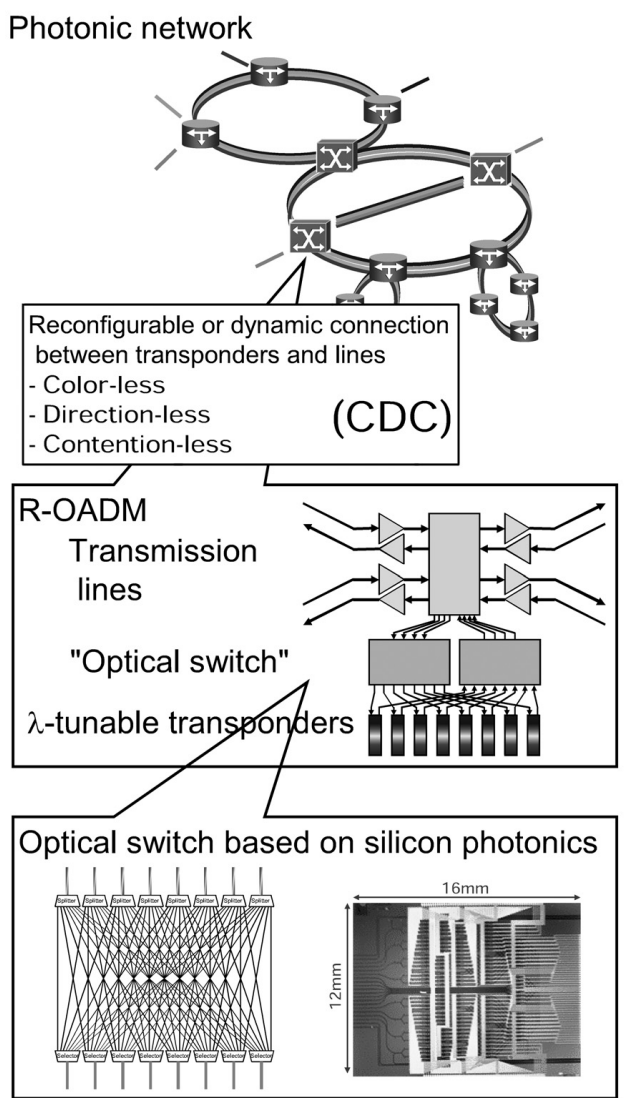

Fig. 7 Optical switches based on silicon photonics for R-OADM.

\section{4. シリコン集積光回路による光スイッチの 光ネットワーク向け応用}

今後の広域光ネットワークでは, R-OADM(Reconfigurable Optical Add Drop Multiplexer)において光パス設定柔軟性 のさらなる向上が求められている. 特に近年はトランス ポンダに対LColor-less, Direction-lessと称される運用形 態の導入が望まれるようになってきた ${ }^{26-27)}$. 従来の R-OADMにおいては, トランスポンダは固定波長で固 定方路に対して運用されており, 送信側のトランスポン ダから受信側のトランスポンダまでの光パスの設定は波 長も経路も固定的であった。これに対し，今後の光ネッ トワークではトランスポンダを任意波長 (Color-less)・任 意方路 (Direction-less)に対して運用可能とすることによ り，光パスを柔軟に設定可能とすることが期待されてい る。トランスポンダの運用効率が向上すると，より少な いトランスポンダ配備数で障害回復, トラフィック調 整, 多方路化への拡張等が可能となる。障害回復に必要 なバックアップ用トランスポンダの数で考えれば, 従来 は1+1で必要であったのに対して大幅な削減が可能で あり，これによる省エネルギー化の効果も大きい。 これ を実現するためには, Fig. 7に示すように, 光ネット ワークの各ノードにおけるトランスポンダと伝送路の接 続経路において，任意の経路に対し任意の波長を割当可 能とする光パス制御が必要であり，基本的には光スイッ 千機能と光合分波機能の組合せが必要となる。具体的に は様々な構成が考えられ，例えば石英光導波路ベースで これを構築した例が報告されている ${ }^{28-29)}$ 。 シリコン集積 光回路技術は，設置面積や消費電力，さらには切替速度 の観点でメリットを打ち出していける ${ }^{10-16)}$. Fig. 7には, 上記の用途に向け，3章で示した $1 \times 8$ 光スイッチをべー スに $8 \times 8$ 分岐選択型光スイッチを構成した例を示し た. $12 \mathrm{~mm} \times 16 \mathrm{~mm}$ の領域に152個の熱光スイッチを集 積化した光回路で構成される。光回路内部における光損 失は, 8 分岐に伴う光損失以外は $5 \mathrm{~dB}$ 以下であった.

5. まとめ

光伝送技術の分野では，光デバイスの小型化・集積化 を進めることで，光デバイスそのものを省エネルギー化 
すると共に, 光デバイス・光伝送が導入可能な領域を拡 大してICT機器・システムを省エネルギー化する取り組 みが進められている。この光デバイス小型化・集積化の 今後を担う技術として，近年，シリコンフォトニクスへ の注目が高まっている。シリコンフォトニクスによる集 積化の現状を概観すると共に，我々が取り組みを進めて いる光スイッチ技術に関して, 省エネルギー化への貢献 ポイントを中心に紹介した。 シリコン熱光スイッチ素子 そのものは，高い屈折率温度係数を利用することにより 低電力駆動が可能である。これを集積した光回路を省工 ネルギーで動作させる上では，素子を個別に調整するこ とを不要にする均一性, 偏光ダイバシティを不要にする 偏光無依存化, 温調を不要にする環境温度無依存化が必 要になる. 熱光スイッチ素子を集積した光回路で構成す る $1 \times 8$ 光スイッチにおいてこれらの特性を兼ね備えた 形で高消光比特性を実現した。また，これらのシリコン 集積光スイッチ技術を広域光ネットワークにおける R-OADMに適用することでトランスポンダの運用の効 率化に有用である。トランスポンダを効率的に運用する ことで配備する台数を抑えることができれば，システム としての省エネルギー化が可能になる，さらに，このよ うな小型・低電力のシリコン熱光スイッチ素子の多数集 積化を可能にすることにより，広域光ネットワークにと どまらず多様な適用領域への展開も可能となる。実用化 に向けては，光回路小型化のメリットを十分に発揮でき るようパッケージング技術も重要になってくる.

本報告に記した内容は, 高橋重樹, 牛田淳, 小倉一郎, 蔵田和彦, 徳島 正敏, 坂内 正宏, 樋野智之, 竹下仁士, 水谷 健二, 田島 章雄, Ming-Bin Yu, Guo-Qiang Loの各 氏との共同研究の成果を含むものであり, 上記の方々に 深く感謝する.

\section{参考文献}

1)「シリコンフォトニクスの最前線」特集号：レーザー研究 35 (2007).

2) A. Narasimha, et al.: Optical Fiber Communication Conference, San Diego, March, 2010, OMV4.

3) G. Masini, et al.: Optical Fiber Communication Conference, Los Angeles, March, 2012, OTu2I.1.

4) X. Zheng, et al.: Opt. Express 19 (2011) 5172.

5) Y. Urino, et al.: Opt. Express 19 (2011) B159.

6) Y. A. Vlasov: IEEE Comm. Mag. 50 (2012) S67.

7) C. R. Doerr, P. J. Winzer, Y.-K. Chen, S. Chandrasekhar, M. S.
Rasras, L. Chen, T.-Y. Liow, K.-W. Ang, and G.-Q. Lo: J. Lightwave Technol. 28 (2010) 520.

8) C. R. Doerr and T. F. Taunay: IEEE Photon. Technol. Lett. 23 (2011) 597.

9) H. Yamada, T. Chu, S. Ishida, and Y. Arakawa: IEEE J. Sel. Top. Quantum Electron. 12 (2006) 1371.

10) T. Chu, H. Yamada , S. Nakamura, M. Tojo, Y. Urino, S. Ishida, and Y. Arakawa: Photonics West, San Jose, January, 2007, 6477-08.

11) 河島他：電子情報通信学会総合大会 (2011年3月) C-3-38.

12) S. Nakamura, T. Chu, M. Ishizaka, M. Tokushima, Y. Urino, M. Sakauchi, I. Nishioka, and K. Fukuchi: European Conference on Optical Communication, Brussels, September, 2008, Tu.4.C.6.

13) M. Sakauchi, I. Nishioka, S. Nakamura, T. Chu, and Y. Urino: Optical Fiber Communication Conference, San Diego, March, 2009, JThA51.

14) S. Nakamura, S. Takahashi, M. Sakauchi, T. Hino, M.-B. Yu, and G.-Q. Lo: Optical Fiber Communication Conference, Los Angeles, March, 2011, OTuM2.

15) T. Hino, M. Sakauchi, J. Kurumida, S. Namiki, S. Takahashi, S. Nakamura, and A. Tajima: Opto-Electronics and Communications Conference, Kaohsiung, July, 2011, 6A1-2.

16) S. Nakamura, S. Takahashi, I. Ogura, J. Ushida, K. Kurata, T. Hino, H. Takeshita, A. Tajima, M.-B. Yu, and G.-Q. Lo: Optical Fiber Communication Conference, Los Angeles, March, 2012 OTu2I.3.

17) N. Sherwood-Droz, H. Wang, L. Chen, B. G. Lee, A. Biberman, K. Bergman, and M. Lipson: Opt. Express 16 (2008) 15915.

18) M. Yang, W. M. J. Green, S. Assefa, J. Van Campenhout, B. G. Lee, C. V. Jahnes, F. E. Doany, C. L. Schow, J. A. Kash, and Y. A. Vlasov: Opt. Express 19 (2011) 47.

19) H. L. R. Lira, S. Manipatruni, and M. Lipson: Opt. Express 17 (2009) 22271.

20) R. Halir, I. Molina-Fernández, A. Ortega-Moñux, J. G. Wangüemert-Pérez, D.-X. Xu, P. Cheben, and S. Janz: J. Lightwave Technol. 26 (2008) 2928.

21) Y. Atsumi, K. Inoue, N. Nishiyama, and S. Arai: Jpn. J. Appl. Phys. 49 (2010) 050206.

22) G. Cocorullo, F. G. Della Corte, and I. Rendina: Appl. Phys. Lett. 74 (1999) 3338

23) T. Tsuchizawa, K. Yamada, H. Fukuda, T. Watanabe, J. Takahashi, M. Takahashi, T. Shoji, E. Tamechika, S. Itabashi, and H. Morita: IEEE J. Sel. Top. Quantum Electron. 11 (2005) 232.

24) A. Barkai, A. Liu, D. Kim, R. Cohen, N. Elek, H.-H. Chang, B. H. Malik, R. Gabay, R. Jones, M. Paniccia, and N. Izhaky: J. Lightwave Technol. 26 (2008) 3860.

25) M. Tokushima, A. Kamei, and T. Horikawa: Appl. Phys. Express 5 (2012) 022202.

26) E. B. Basch, R. Egorov, S. Gringeri, and S. Elby: IEEE J. Sel. Top. Quantum Electron. 12 (2006) 615.

27) P. Roorda and B. Collings: Optical Fiber Communication Conference, San Diego, March, 2008, NWE2.

28) K. Mizutani, M. Sakauchi, and A. Tajima: European Conference on Optical Communication, Torino, September, 2010, P3.11.

29) T. Watanabe, K. Suzuki, T. Goh, K. Hattori, A. Mori, T. Takahashi, T. Sakamoto, K. Morita, S. Sohma, and S. Kamei: $O p$ tical Fiber Communication Conference, Los Angeles, March, 2011, OTuD3.

熱光学効果 (thermo-optical effect)・キャリアプラズマ

\section{効果 (carrier plasma effect)}

固体中では, 一般に, 光の屈折率は温度に依存する。 局所的な加熱により, その領域の屈折率を変化させて, デバイスに活用する場合を, 熱光学効果と呼んでいる. 熱光学効果の大きさは, 屈折率温度係数で表わされ， シ リコンの場合，石英の 20 倍程度である，当然ながら，環 境温度等の影響によりデバイス全体の温度が変化すれば 屈折率も変化することになる。また，プラズマ中を伝搬
する電磁波の分極率はプラズマ密度に比例する。これと 同様の状況は, 半導体中で光の屈折率がキャリア(電子 または正孔またはその両方)の密度に依存する現象とし て現れる。これをキャリアプラズマ効果と呼んでいる. シリコン中においても，キャリア密度の変調により屈折 率を変調することができる.

(中村 滋) 